\title{
Cyclic AMP regulates expression of the gene coding for a mouse vas deferens protein related to the aldo-keto reductase superfamily in human and murine adrenocortical cells
}

\author{
C Aigueperse, A Martinez, A M Lefrançois-Martinez, G Veyssière \\ and $\mathbf{C l}$ Jean
}

Reproduction et Développement, UMR CNRS 6547, Université Blaise Pascal, Les Cézeaux, 63177 Aubière, Cédex, France

(Requests for offprints should be addressed to C Aigueperse)

\begin{abstract}
Mouse vas deferens protein (MVDP) is a member of the aldo-keto reductase superfamily. The regulation of MVDP gene expression by activators of the protein kinase A signalling pathway was investigated in human (H295-R) and murine (Y1) adrenocortical carcinoma cells. Immunoblotting with polyclonal antibodies showed that MVDP is expressed in adrenal glands from mouse, rat, rabbit and guinea-pig, probably under the control of ACTH. In both adrenocortical cell lines used, MVDP is
\end{abstract}

constitutively synthesized and its accumulation is increased by treatment with cAMP or forskolin. MVDP mRNA steady-state levels were up-regulated by forskolin in adrenocortical cells by a process that does not require de novo protein synthesis. The results suggest that cAMP is at least one of the key regulators of adrenal MVDP expression and that this effect is direct.

Journal of Endocrinology (1999) 160, 147-154

\section{Introduction}

Aldo-keto reductases represent a multigene superfamily of monomeric proteins that are widely distributed in man and animals (reviewed by Bhatnagar \& Srivastava 1992). Many subfamilies have been recognized, including aldehyde and aldose reductases, a number of hydroxysteroid dehydrogenases and plant chalcone reductases. The various aldo-keto reductases show broad overlapping substrate specificities for aldehydes and ketones, including xenobiotics as well as endogenous compounds (Bohren et al. 1989). Recent data concerning methotrexate resistance in Leishmania and cysteine protease inhibitor resistance in Chinese hamster ovary $(\mathrm{CHO})$ cells suggest that members of the aldo-keto reductase superfamily may be used as a detoxifying system (Callahan \& Beverley 1992, Inoue et al. 1993).

Among the aldo-keto reductase family, aldose reductase is one of the best studied because of its possible role in the development of some diabetic complications such as retinopathy, neuropathy and nephropathy (Kinoshita \& Nishimura 1988). Recently, it has been suggested that the induction of aldose reductase during oxidative stress might represent an important cellular anti-oxidant defence mechanism that could be involved in the pathogenesis of atherosclerosis (Spycher et al. 1997). Aldose reductase is a ubiquitous 'house keeping' enzyme, probably functional in all cells, that has been isolated and purified from a number of human and animal tissues (Bhatnagar \& Srivastava 1992). For many years, the activity of aldose reductase was assumed to be very low or absent in the mouse (Varma \& Kinoshita 1974). However, the cloning and sequencing of murine aldose reductase have recently been reported (Daoudal et al. 1995, Gui et al. 1995). Interestingly, two aldose reductase-like sequences similar to human and rat aldose reductases have recently been reported in the mouse. Adult mouse vas deferens contains a large amount of a $34.5 \mathrm{kDa}$ protein (mouse vas deferens protein (MVDP)) (Taragnat et al. 1988). The amino acid sequence of MVDP exhibits a high degree of identity with members of the aldo-keto reductase superfamily, especially aldose reductase from human placenta (71\%) and rat lens (69\%) (Pailhoux et al. 1990). It has been shown that testosterone is the signal that triggers MVDP gene expression at the protein and mRNA levels (Martinez et al. 1990, Taragnat et al. 1990). Fibroblast growth factor (FGF)-1 can induce the expression of a transcript referred to as FR-1 (Donohue et al. 1994). The sequence identity between this FR-1 and rat or human aldose reductase is approximately $70 \%$. FR-1 mRNA is detectable in a number of mouse tissues but is most abundant in newborn liver and in adult intestine, ovary and testis (Donohue et al. 1994). The amino acid sequence identity between FR-1 and MVDP is $82 \%$. Additional proteins with a high degree of sequence identity with MVDP have recently been identified. 
During hepatocarcinogenesis, the most prominent tumourassociated protein variant (spot 17 ) revealed a $92 \%$ identity with MVDP (Zeindl-Eberhart et al. 1994). An inducible aldo-keto reductase from $\mathrm{CHO}$ cells shows greatest amino acid sequence identity to mouse FR-1 and MVDP (92 and 80\% respectively) (Hyndman et al. 1997). Although aldose reductases and other members of the aldo-keto reductase family are involved in cellular homeostasis (Bhatnagar \& Srivastava 1992), little is known about the signal transduction pathways that mediate the response of these genes to extracellular signalling molecules. MVDP and FR-1 are unique among the aldo-keto reductase family in that their expression appears to be transcriptionally regulated by androgen (Taragnat et al. 1988, Martinez et al. 1990, Fabre et al. 1994) and by growth factors (Donohue et al. 1994) respectively.

High levels of MVDP mRNA were found in the mouse vas deferens but not in that of other species studied, suggesting zoological specificity (Martinez et al. 1990). Because high levels of MVDP mRNA were recently found in the mouse adrenal (Lau et al. 1995), the first objective of the current study was to determine if adrenals express MVDP at mRNA and protein levels, and if this expression is restricted to the mouse species. The second objective was to investigate whether cAMP can affect MVDP expression, since this nucleotide is directly involved in the control of glucocorticoid secretion by adrenocorticotrophin (ACTH) (Hanukoglu et al. 1990).

\section{Materials and Methods}

\section{Cell culture}

Murine Y1 adrenocortical tumour cells (Yasumura et al. 1966) were grown in Dulbecco's modified Eagle's-Ham's F-12 medium (DME/F12) supplemented with 10\% fetal calf serum, glutamine $(2 \mathrm{mM})$, penicillin (100 units/ml) and streptomycin $(100 \mu \mathrm{g} / \mathrm{ml})$.

Human H295-R adrenocortical carcinoma cells, obtained from the American Type Culture Collection (Rockville, MD, USA), were grown in DME/F12 medium supplemented with 3\% fetal calf serum, $2 \%$ Ultroser G (Life Technologies Ltd, Paisley, UK), 1\% ITS (insulin, transferrin, sodium selenite) (Sigma, St Louis, MO, USA), penicillin (100 units $/ \mathrm{ml}$ ) and streptomycin $(100 \mu \mathrm{g} / \mathrm{ml})$.

\section{Northern blot analysis}

Total RNA was extracted from Y1 or H295-R cells with RNAzol (Bioprobe Systems, Montreuil-sous-bois, France), according to the manufacturer's instructions. Twenty or $30 \mu \mathrm{g}$ of total RNA were electrophoresed in a $1 \%(\mathrm{w} / \mathrm{v})$ agarose, $2 \cdot 2 \mathrm{M}$ formaldehyde gel and transferred to nylon filters. The filters were placed for $5 \mathrm{~min}$ in u.v. light. The probe used to detect MVDP mRNA was obtained by pGEM-MVDP clone digestion with EcoRI and BamHI, which released MVDP cDNA $(1.2 \mathrm{~kb})$. The cDNAs were labelled with $\left[{ }^{32} \mathrm{P}\right] \mathrm{dCTP}$ using the Megaprime DNA Labelling System (Amersham France SA, Les Ulis, France). Prehybridization was done for $1.5 \mathrm{~h}$ at $65{ }^{\circ} \mathrm{C}$ in a solution containing $3 \times \mathrm{SSC}$, polyvinylpyrrolidone $(0 \cdot 2 \%)$, ficoll $(0 \cdot 2 \%)$, polyethylene glycol $(5 \%)$, glycine (1\%), SDS (1\%) and $100 \mu \mathrm{g} / \mathrm{ml}$ denatured salmon sperm DNA. Hybridization was performed overnight at $65^{\circ} \mathrm{C}$ in the same solution containing $1 \times 10^{6}$ c.p.m./ml of ${ }^{32} \mathrm{P}-$ labelled MVDP cDNA probes. Filters were washed at $65{ }^{\circ} \mathrm{C}$. To verify the relative quantities of MVDP mRNA, Northern blots were stripped and rehybridized in the same buffer described above, at $65^{\circ} \mathrm{C}$ with a ${ }^{32} \mathrm{P}-$ labelled $18 \mathrm{~S}$ rRNA cDNA provided by $\mathrm{N}$ Ghyselinck (LGME, INSERM U184, Strasbourg, France) or a ${ }^{32} \mathrm{P}$-labelled poly A binding protein (PABP) cDNA (Grange et al. 1987). Autoradiography was carried out by exposing the blots to XAR-S films (Kodak) for $48 \mathrm{~h}$ with an intensifying screen at $-80^{\circ} \mathrm{C}$. The maximum induction factors of MVDP mRNA concentrations under forskolin treatment were quantified by densitometric scanning of the Northern blots X-ray film using specially developed software (Grafteck, Aix en Provence, France) on an Apple MacIntosh computer. The mean values (from three to five independent experiments) have been calculated between 1 and $3 \mathrm{~h}$ (Y1 cells) or between 1 and $6 \mathrm{~h}$ (H295-R cells) of forskolin treatment.

\section{Western blot analysis}

Frozen individual tissue samples were homogenized in 100-300 $\mu \mathrm{l} 250 \mathrm{mM}$ Tris-HCl (pH 7·5), $0 \cdot 4 \mathrm{mM}$ PMSF using a glass-glass tissue homogenizer and centrifuged in a microfuge at $10000 \mathrm{~g}$ at $4{ }^{\circ} \mathrm{C}$ for $15 \mathrm{~min}$. For Western blot analysis of MVDP content of cells, a fraction of cell sample was collected before RNAzol extraction. The concentration of soluble proteins was determined by the Bradford method (Bio-Rad Laboratories GmbH, Munich, Germany). Soluble tissue or cellular extracts $(10-20 \mu \mathrm{g}$ protein) were subjected to SDS-PAGE on $10 \%$ acrylamide gels and transferred to nitrocellulose membranes in a Bio-Rad apparatus according to the manufacturer's instructions. To block non-specific protein binding sites the nitrocellulose was incubated for $1 \mathrm{~h}$ at room temperature in TBST $(50 \mathrm{mM}$ Tris- $\mathrm{HCl}(\mathrm{pH} 8), 150 \mathrm{mM}$ $\mathrm{NaCl}, 0 \cdot 1 \%(\mathrm{v} / \mathrm{v})$ Tween 20$)$ containing $5 \%(\mathrm{w} / \mathrm{v})$ nonfat dried milk and the incubation with the primary monoclonal or polyclonal antibody was for $1 \mathrm{~h}$ at room temperature as previously described (Martinez et al. 1990, Taragnat et al. 1990). Following three washes in TBST, the sheets were incubated for $1 \mathrm{~h}$ at room temperature with the second antibody (peroxidase-conjugated antirabbit $\operatorname{IgG}$ (Boehringer Mannheim GmbH, Germany) 
diluted 1:15000. The blots were washed again, and peroxidase activity was detected by autoradiography with the ECL enhanced chemiluminescence system (Amersham).

\section{Immunocytochemistry}

Immediately after killing, vas deferens and adrenals were fixed in 75\% ethanol, $25 \%$ acetic acid for $30 \mathrm{~min}$, dehydrated in absolute ethanol and embedded in paraffin wax. After dewaxing, slides containing sections of $6 \mu \mathrm{m}$ were incubated overnight at $4{ }^{\circ} \mathrm{C}$ with primary antibody diluted 1:80 in PBS containing 5\% (w/v) non-fat dried milk (Martinez et al. 1989). Slides were then rinsed three times in PBS and treated for $2 \mathrm{~h}$ at room temperature with anti-rabbit-peroxidase antibody diluted 1:400. Peroxidase activity was revealed using standard immunoperoxidase procedures (Carlson et al. 1988). Control slides were obtained by incubation of tissue sections with nonimmune serum.

\section{Plasmid constructs}

All plasmid constructs were prepared using standard methods (Sambrook et al. 1989). The mouse mammary tumour virus-chloramphenicol acetyl transferase (MMTVCAT) vector contains the upstream sequence of the long terminal repeat promoter of the MMTV in front of the CAT reporter gene. The pSV-ARo vector contains an SV40 promoter directing the transcription of the full-length human androgen receptor cDNA (Brinkmann et al. 1989).

\section{Transient transfections and CAT assays}

One day before transfection, Y1 cells were plated at a density of $10^{6}$ cells $/ 60 \mathrm{~mm}$ dish. Two hours prior to addition of the calcium phosphate/DNA precipitates, the medium was replaced with Dulbecco's modified Eagle's medium containing $10 \%$ fetal calf serum. Transfection was performed by the calcium phosphate method (Chen \& Okayama 1987) using $2 \mu \mathrm{g}$ MMTV-CAT and $1.5 \mu \mathrm{g}$ pSV-ARo vectors. The medium was changed the morning after transfection, and the cells were maintained in the presence or absence of $10^{-6} \mathrm{M} 5 \alpha$-dihydrotestosterone (DHT) for $48 \mathrm{~h}$.

CAT activity of cell extracts was assayed according to the method of Neumann et al. (1987).

Samples of proteins $(20 \mu \mathrm{l})$ were incubated in $80 \mu \mathrm{l}$ $250 \mathrm{mM}$ Tris $-\mathrm{HCl}(\mathrm{pH} 7 \cdot 8), 0 \cdot 2 \mathrm{mM}$ acetyl coenzyme A, $0 \cdot 12 \mu \mathrm{Ci}$ of $\left[{ }^{14} \mathrm{C}\right]$ chloramphenicol for $3 \mathrm{~h}$ at $37^{\circ} \mathrm{C}$. After thin layer chromatography and autoradiography, acetylated and non-acetylated forms were excised and quantified by scintillation counting. CAT activity corresponds to the ratio of acetylated-form radioactivity to total radioactivity (both forms).

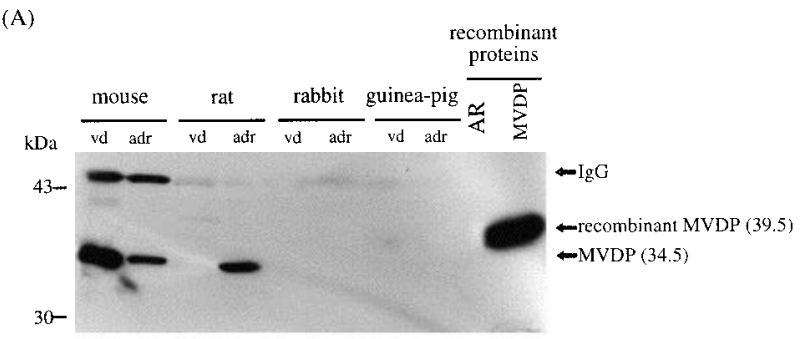

(B)

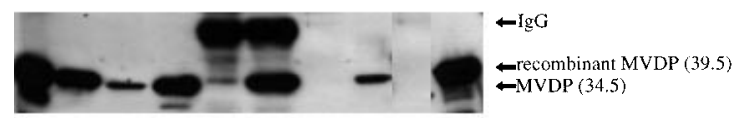

Figure 1 Western blot analysis of $20 \mu \mathrm{g}$ protein from vas deferens (vd) and adrenal glands (adr) from mouse, rat, rabbit and guinea-pig and $10 \mu \mathrm{g}$ recombinant murine aldose reductase (AR) and MVDP. After SDS-PAGE, the proteins were transferred to nitrocellulose and incubated with (A) monoclonal (1:700) or (B) polyclonal (1:3000) antibody specific for MVDP.

\section{Animals}

Mice of the Swiss strain (CD-1; Charles River, Saint Aubin les Elbeuf, France) were used. To investigate the role of pituitary ACTH, adult males were treated with corticosterone $(75 \mu \mathrm{g}$ dissolved in sesame oil were injected s.c. every day) for 7 days and killed $6 \mathrm{~h}$ after the last injection. Tissues (vasa deferentia and adrenals) were removed, frozen in liquid nitrogen and stored at $-70{ }^{\circ} \mathrm{C}$ until Western blot analysis.

\section{Results}

\section{Expression of MVDP in adrenal glands}

High levels of MVDP mRNA have been found in the mouse adrenal gland (Lau et al. 1995). By Western blot analysis using the monoclonal antibody against MVDP, antigens corresponding to this protein could be detected in adrenal glands from mouse and rat (Fig. 1A). By immunoblotting, a cross-reaction was found between the antiMVDP polyclonal antibody and proteins from adrenal glands of rat, rabbit and guinea-pig (Fig. 1B). Although not quantified, the amount of MVDP in the adrenals was higher than that in vas deferens, except in mouse. As shown with recombinant proteins, the polyclonal and monoclonal antibodies used do not cross-react with aldose reductase.

Immunohistochemical staining was performed to localize the protein in histological sections of the adrenal gland. Figure $2 \mathrm{~A}$ shows that there is a strong staining in the cortex but not in the medulla, and that the reactivity seems to be restricted to the zona fasciculata. The staining reaction can be abolished by preabsorbing the primary 
(A)

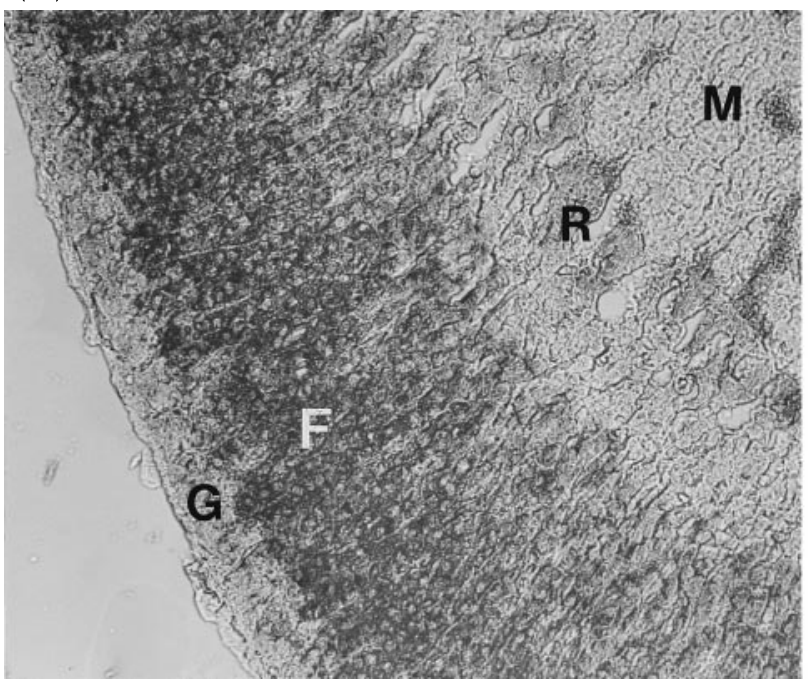

(B)

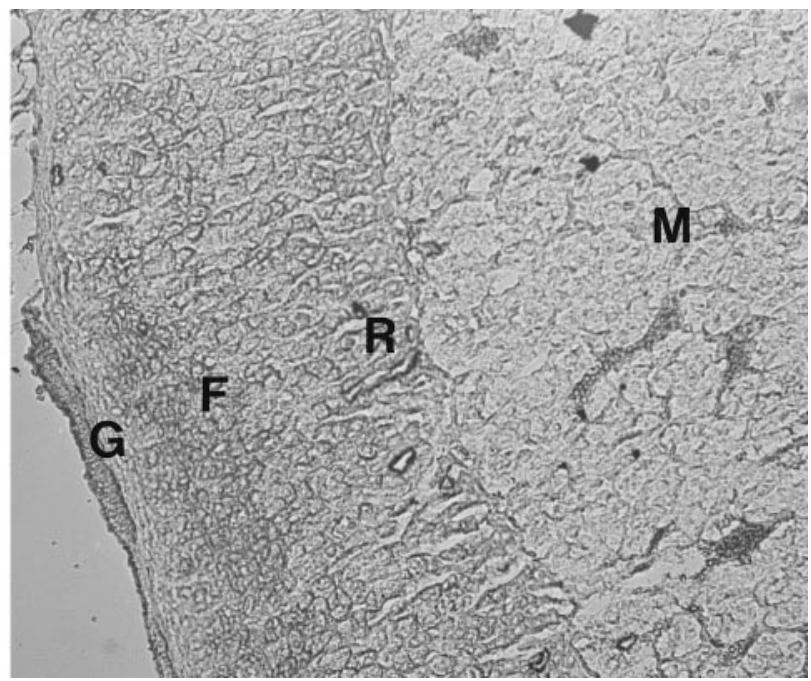

Figure 2 Localization of MVDP in sections of adrenals from adult male mice. Tissue sections were treated with the anti-MVDP serum followed by incubation with (A) the secondary anti-rabbit-peroxidase antibody or (B) the preimmune serum. MVDP was detected only in the zona fasciculata (F). R: zona reticularis; $G$, zona glomerulosa; $M$, medulla.

antibody with antigen and no staining was observed when tissue sections were incubated with non-immune serum (Fig. 2B).

\section{Androgens do not activate MVDP expression in cultured} adrenocortical cells

To avoid the limitations inherent in whole animal studies, we have used adrenocortical tumour cells of mouse origin (clone Y1), and human H295-R adrenocortical carcinoma cells. Expression of MVDP and its mRNA is dependent on the androgen status of animals (Taragnat et al. 1988, Martinez et al. 1990) and vas deferens epithelial cell cultures express MVDP in response to androgens (Manin et al. 1992). To test whether MVDP expression in adrenals is influenced by androgens, adrenocortical cells were cultured in the presence of DHT or the synthetic androgen R1881.

Total RNA was extracted from cultured cells and the RNA blot was hybridized with the MVDP cDNA labelled with ${ }^{32} \mathrm{P}$. In $\mathrm{Y} 1$ cell lines the probe was found to hybridize a single band (Fig. 3), the approximate size of which $(1.4 \mathrm{~kb})$ is similar to the MVDP mRNA found in vas deferens. When DHT or R1881 was present during $24 \mathrm{~h}$, the level of MVDP mRNA was not significantly affected in Y1 cells. Similar results were obtained using H295-R cells (not shown).

MMTV-CAT was used to test the presence of functional androgen receptors in adrenocortical cells, since it is well known that the hormone response elements of MMTV are activated by a variety of steroids in different cell lines (Parker et al. 1987). As shown in Fig. 4, MMTV-CAT does not respond to $10^{-6} \mathrm{M}$ DHT, suggesting that $\mathrm{Y} 1$ adrenocortical cells lack androgen receptors. After cotransfection of the androgen receptor expression vector (pSV-ARo), significant induction of CAT activity was observed with extract from cells stimulated by $10^{-6} \mathrm{M}$ DHT. Similar observations were made after cotransfection of the progesterone receptor expression vector and stimulation by progesterone or R1881 (not shown).

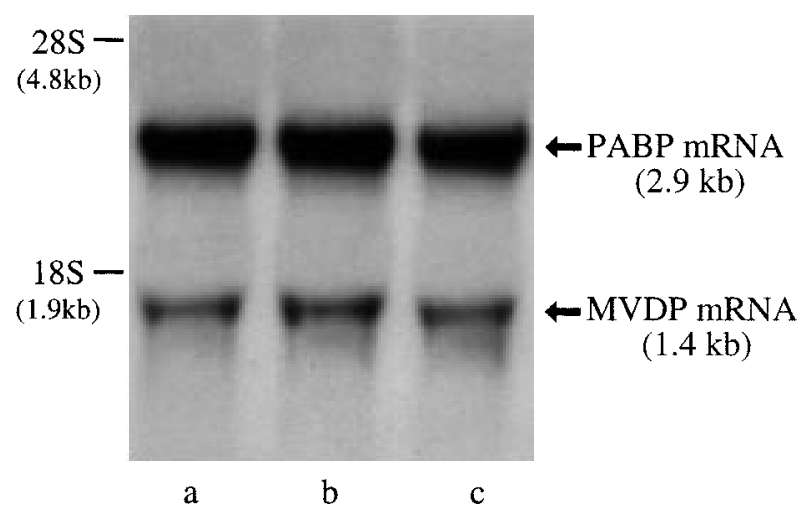

Figure 3 Expression of MVDP mRNA in murine adrenocortical cells (Y1) cultured in the absence (a) or presence of (b) $10^{-6} \mathrm{M}$ DHT or (c) $10^{-7} \mathrm{M} \mathrm{R} 1881$ for $48 \mathrm{~h}$. Thirty $\mu \mathrm{g}$ of total RNA were loaded per well and hybridized with either the ${ }^{32}$ P-labelled MVDP cDNA or PABP (Grange et al. 1987) cDNA probe. 


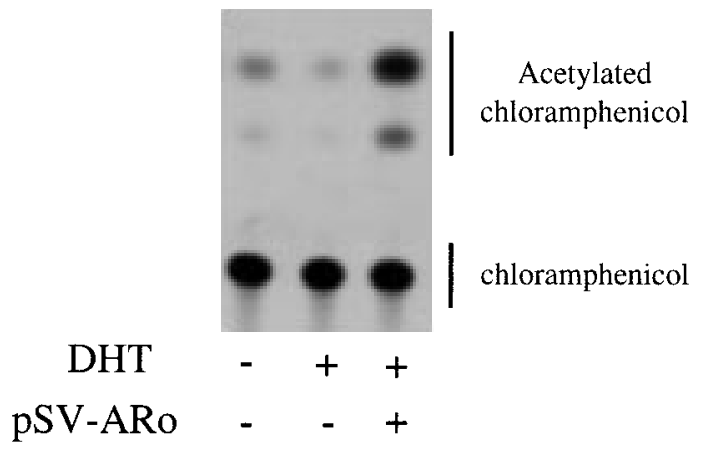

Figure 4 Search for functional androgen receptors in $\mathrm{Y} 1$ cells. Cells were seeded at a density of $10^{6}$ per $60 \mathrm{~mm}$ plastic dish and transfected $24 \mathrm{~h}$ later with $2 \mu \mathrm{g}$ MMTV-CAT vector and cotransfected with $1.5 \mu \mathrm{g}$ pSV-ARo vector using the calcium phosphate method (Chen \& Okayama 1987). The medium was changed the morning after transfection, and the cells were maintained in the presence or absence of $10^{-6} \mathrm{M} \mathrm{DHT}$ for $48 \mathrm{~h}$. Autoradiogram of CAT gene expression.

Activation of the protein kinase $A(P K A)$ signalling pathway increases $M V D P$ and MVDP $m R N A$ levels in adrenocortical cells

In the adrenal gland, steroidogenesis is stimulated by ACTH through elevation of cAMP and the subsequent activation of cAMP-dependent PKA (Hanukoglu et al. 1990). To examine possible regulation of MVDP expression by the PKA transduction pathway, Y1 adrenocortical cells were cultured in the presence of db-cAMP or steroids. As shown in Fig. 5, treatment of cells for $36 \mathrm{~h}$ with $1 \mathrm{mM}$ db-cAMP resulted in an increase in the expression of MVDP. The ability of db-cAMP to induce MVDP expression was not shared by R1881, progesterone, dexamethasone, aldosterone or oestradiol, indicating that this induction is independent of the steroidogenesis stimulation.

To determine the time course of MVDP induction, cultured $\mathrm{Y} 1$ and $\mathrm{H} 295-\mathrm{R}$ cells were treated with $10^{-5} \mathrm{M}$ forskolin, an activator of cAMP synthesis in cells, for increasing periods of time. On the basis of Western blot analysis of cell extracts, MVDP was expressed at very low levels at $6 \mathrm{~h}$, and increased about 37-fold until $19 \mathrm{~h}$ in Y1 cells (Fig. 6A). In H295-R cells, MVDP induction occurred $12 \mathrm{~h}$ after forskolin addition and varied little until 24 h (Fig. 6b).

To assess if these increases in MVDP immunoreactivity were potentially transcriptionally regulated, steady-state levels of MVDP mRNA were examined following PKA activation. Treatment of cells with $10^{-5} \mathrm{M}$ forskolin for $2 \mathrm{~h}$ (Y1 cells) or $1 \mathrm{~h}$ (H295-R cells) led to expression of MVDP mRNA. The stimulating effect of forskolin is time dependent and induction is about 10-fold after $3 \mathrm{~h}$ (Y1 cells) or 9-fold after $6 \mathrm{~h}$ (H295-R cells) compared with levels determined after $1 \mathrm{~h}$ induction (Fig. $6 c, d$ ). The

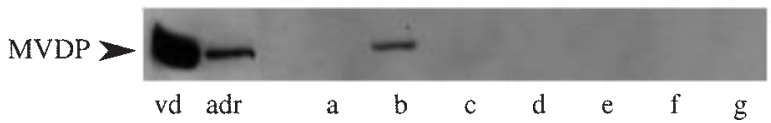

Figure 5 Expression of MVDP in murine adrenocortical cells (Y1). Western blot analysis of $20 \mu \mathrm{g}$ protein from vas deferens (vd) and adrenal glands (adr) from mouse and cells cultured (a) in basal serum-free medium or with (b) $1 \mathrm{mM}$ db-cAMP, (c) $10^{-7} \mathrm{M}$ R1881, (d) $10^{-6} \mathrm{M}$ progesterone, (e) $10^{-6} \mathrm{M}$ dexamethasone, (f) $10^{-6} \mathrm{M}$ aldosterone, (g) $10^{-6} \mathrm{M}$ oestradiol for $36 \mathrm{~h}$. After SDS-PAGE, the proteins were transferred to nitrocellulose and incubated with monoclonal antibody specific for MVDP (1:700).

accumulation of MVDP and of its mRNA had a closely related developmental pattern. However, whereas the induction of MVDP mRNA was maximal $3 \mathrm{~h}$ (Y1 cells) or $6 \mathrm{~h}$ (H295-R cells) after forskolin addition, the maximal MVDP levels were detected only at $19 \mathrm{~h}$ (Y1 cells) or $24 \mathrm{~h}$ (H295-R cells). This lag period probably corresponds to the translation of the mRNA accumulated at $3 \mathrm{~h}$ (Y1 cells) or $6 \mathrm{~h}$ (H295-R cells).

Treatment of Y1 cells for $36 \mathrm{~h}$ with $10^{-6} \mathrm{M} \mathrm{ACTH}$ had no significant effect on MVDP mRNA levels (not shown).

To determine whether cAMP exerts its action through newly synthesized proteins, the effect of cycloheximide, a protein synthesis inhibitor (which blocks the peptidyl transferase reaction on ribosomes in eukaryotes), on MVDP mRNA levels was examined. Y1 and H295-R cells were treated for $6 \mathrm{~h}$ and $24 \mathrm{~h}$ with $2 \cdot 8 \mu \mathrm{g} / \mathrm{ml}$ cycloheximide alone or in combination with forskolin. As shown in Fig. $6 c, d$, when cycloheximide was given in concert with forskolin, the stimulatory effect of the activator on MVDP mRNA levels was unchanged in Y1 or even strengthened in $24 \mathrm{~h}$ treated H295-R cells. Western blot analysis showed that this treatment abolished the increase in MVDP levels induced by forskolin, indicating that the dose of cycloheximide used is sufficient to inhibit protein synthesis (Fig. 6a,b).

\section{Hormonal regulation of MVDP in adrenal glands}

To determine whether MVDP expression in adrenals might be induced by cAMP, we studied the effects of exogenous glucocorticoids which have a direct negative feedback effect on pituitary ACTH secretion. As shown in Fig. 7, corticosterone treatment for 7 days strongly reduced MVDP expression in adrenals but not in the vas deferens from adult males.

\section{Discussion}

It has been recently shown that the expression of MVDP is not restricted to the vas deferens, since high levels of 
(a)

(b)
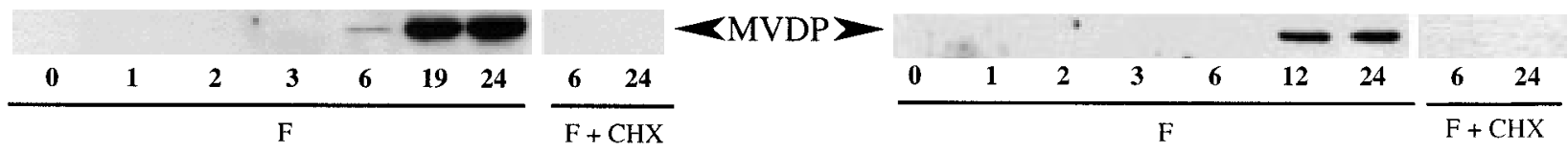

(C)

(d)

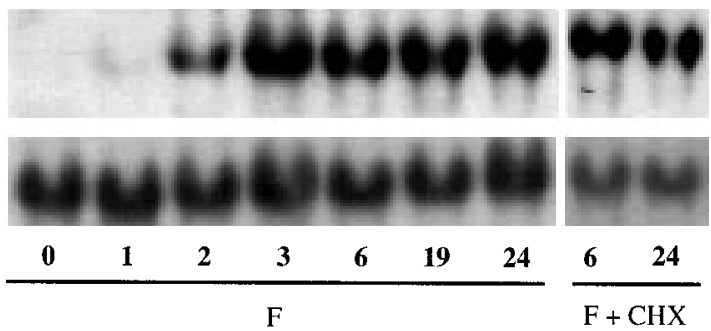

MVDP mRNAs

18S rRNA

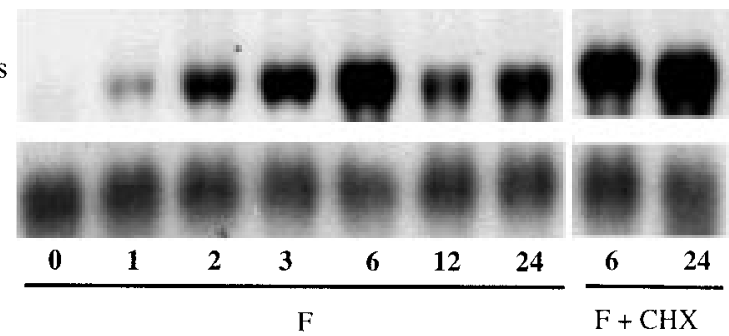

Figure 6 Time-dependent effect of forskolin on MVDP and MVDP mRNA levels in $\mathrm{Y} 1(a, b)$ and H295-R (c,d) cell cultures. Cells were cultured in basal serum-free medium in the presence of $10^{-5} \mathrm{M}$ forskolin (F) for $0,1,2,3,6$, 19, (or 12) or $24 \mathrm{~h}$ or in the presence of $10^{-5} \mathrm{M}$ forskolin concomitantly with $2.8 \mu \mathrm{g} / \mathrm{ml}$ cycloheximide $(\mathrm{CHX})$ for 6 and $24 \mathrm{~h}$. $(a, b)$ Western blot analysis of $20 \mu \mathrm{g}$ protein from (a) Y1 and (b) H295-R cells. After SDS-PAGE, the proteins were transferred to nitrocellulose and incubated with monoclonal antibody specific for MVDP (1:700). (c,d) Northern blot analysis of total RNA extracted from (c) Y1 and (d) H295-R cells. Twenty $\mu$ g total RNA were loaded per well and hybridized with either the ${ }^{32}$ P-labelled MVDP CDNA or 18S rRNA cDNA probe.

MVDP mRNA were found in the adrenal glands, whereas low levels were detected in several tissues including eye, intestine, seminal vesicle, kidney, liver, testis and lung (Lau et al. 1995). We report here that, using a specific polyclonal antibody, MVDP is present in large amounts in mouse, rat, rabbit and guinea-pig adrenal glands. MVDP mRNA and protein were also detected in the two cell lines used in these studies: the murine Y1 adrenocortical tumour cell line, and the human H295-R adrenocortical carcinoma cells. Thus it appears that the expression

\section{vas deferens adrenals}

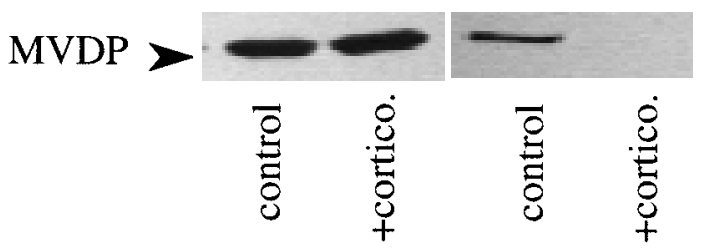

Figure 7 Hormonal regulation of MVDP in adrenal glands. Adult male mice were treated with corticosterone for 7 days and killed $6 \mathrm{~h}$ after the last injection. Western blot analysis of $10 \mu \mathrm{g}$ protein from vas deferens and adrenal glands. After SDS-PAGE, the proteins were transferred to nitrocellulose and incubated with monoclonal antibody specific for MVDP (1:700). of MVDP in the adrenal glands is not specific for the mouse.

The structural zonation of the adrenal cortex roughly correlates with the biosynthesis of different steroids. In the mature gland, the zona glomerulosa synthesizes mineralocorticoids, whereas fasciculata, and less importantly the reticularis, synthesize glucocorticoids and androgens. MVDP was localized in the zona fasciculata, suggesting that this protein may be involved in the metabolism of adrenal steroids. It has been shown recently that degradation of steroids by reduction of their aldehyde and ketone groups may result primarily, not from specific dehydrogenases, but from the broad specificity of enzymes of the aldo-keto reductase superfamily (Stolz et al. 1991, 1993, Warren et al. 1993). Recently, it has been shown that aldose reductase is a major reductase for isocaproaldehyde, a product of side-chain cleavage of cholesterol, in human and animal adrenal glands (Matsuura et al. 1996). Hence, the homology of MVDP with some hydroxysteroid dehydrogenases may offer a clue to its function in adrenals. The enzymatic nature of MVDP has not yet been demonstrated. However, the degree of homology to aldose reductases, and the conservation of amino acid residues known for their importance in NADPH binding and catalytic activity, suggest that MVDP has NADPHdependent reductase activity (Daoudal et al. 1995). There is a great variability in tissue MVDP levels and the expression of the MVDP gene is regulated by different 
factors (see below). These observations suggest that MVDP can be involved in more specific physiological roles in tissues which contain high levels of the protein, i.e. vas deferens and adrenals.

Little is known about the factors which can regulate the expression level of aldo-keto reductase family genes. Regulation by hypertonicity is now well established for the human, rabbit, and mouse aldose reductase genes, and tonicity-responsive elements have been identified in the promoters (Ferraris et al. 1994, Daoudal et al. 1997, Ko et al. 1997). The FR-1 gene is induced by growth factors such as FGF, epidermal growth factor and platelet-derived growth factor, and by phorbol esters (Donohue et al. 1994). Similarly, expression of aldose reductase in astrocytes is due to the effects of FGF (Jacquin-Becker \& Labourdette 1997). The expression of the aldose reductase gene in the ovary seems to be regulated by gonadotrophic hormones (Iwata et al. 1996). Although androgens are hormonal regulators of MVDP in the vas deferens (Taragnat et al. 1988, Martinez et al. 1990), the mechanisms controlling expression of this gene in other tissues remain unknown. $\mathrm{ACTH}$ regulates the synthesis and release of various adrenal steroid hormones, especially those of glucocorticoids. In adrenocortical cells, the hormonal induction is mediated predominantly by increases in intracellular cAMP and subsequent activation of the PKA signalling pathway (Hanukoglu et al. 1990). In this report we show that, in murine and human adrenocortical cells, the MVDP gene is induced by cAMP at mRNA and protein levels. The time course of the induction demonstrates that this is indeed a relatively early transcriptional response of adrenocortical cells to cAMP. The transcripts of the MVDP gene were first detected after $2 \mathrm{~h}$ of forskolin treatment and were fully induced within $3 \mathrm{~h}$ ( $\mathrm{Y} 1$ cells). MVDP mRNA levels do not increase in magnitude with longer exposure. Our results suggest that Y1 cell lines used in these experiments lack androgen receptor. Thus activation of MVDP gene expression by cAMP in cultured adrenocortical $\mathrm{Y} 1$ cells cannot be due to the steroidogenic effects of this nucleotide. Our preliminary in vivo studies suggest that in adrenals MVDP expression is stimulated by ACTH. The effects of ACTH on steroidogenesis can be divided into acute effects, which occur within minutes, and chronic effects, which require hours or days (Simpson \& Waterman 1988). The acute effect of ACTH is to increase mobilization and delivery of cholesterol to the mitochondrial inner membrane, where it is converted to pregnenolone by the side-chain cleavage enzyme P450 scc (Jefcoate et al. 1987). In contrast, the chronic effects of ACTH result from increased transcription of the steroidogenic genes and general trophic actions on adrenocortical cells (Simpson \& Waterman 1988). The MVDP gene showed a significant lag period ( $2 \mathrm{~h}$ in $\mathrm{Y} 1$ cells) between the time forskolin was added to the medium and when MVDP mRNA levels began to rise significantly. Thus the time course of MVDP induction by forskolin is similar to the delayed induction described for cAMPinduced steroidogenic genes in adrenals (John et al. 1986). However, cycloheximide experiments suggest that cAMP induction of the MVDP gene is direct and does not require the presence of newly synthesized labile proteins. In contrast, induction of steroidogenic enzymes by cAMP is sensitive to cycloheximide treatment, leading to the proposal that cAMP induces steroidogenic gene expression by an indirect mechanism (Bokar et al. 1988). Recently, it has been suggested that transcription factors such as steroidogenic factor 1 (SF-1) and SV40-specific factor 1 (Sp1) may act as mediators of cAMP-induced P450 scc gene expression (Liu \& Simpson 1997). Interestingly, the promoter region of the MVDP gene contains two sequences homologous with cAMP response element (positions -1746 and -1019 ) and potential recognition sequences for the SF-1 and Sp1 factors (positions -453 and -44 respectively).

Activation of the MVDP gene by androgens in vas deferens epithelial cells is sensitive to cycloheximide, indicating a need for de novo protein synthesis (Dassouli et al. 1994). Thus the stimulation of the MVDP gene is regulated by different pathways depending on cell type. Further functional characterization of the MVDP promoter region will help to elucidate the role of putative trans-acting factors in the control of MVDP gene expression.

\section{References}

Bhatnagar A \& Srivastava SK 1992 Aldose-reductase: congenial and injurious profiles of an enigmatic enzyme. Biochemical Medicine Metabolic Biology 48 91-121.

Bohren KM, Bullock B, Wermuth B \& Gabbay KH 1989 The aldo-keto reductase superfamily. Journal of Biological Chemistry 264 9547-9551.

Bokar JA, Roesler WJ, Vanderbark GR, Kaetzel DM, Hanson RN \& Nilson JH 1988 Characterization of the cAMP responsive elements from the genes for the $\alpha$-subunit of glycoprotein hormones and phosphoenolpyruvate carboxykinase (GTP). Journal of Biological Chemistry 263 19740-19747.

Brinkmann AO, Faber PW, Van Rooij HCJ, Kuiper GGJM, Ris C, Klaassen P, Van der Korput JAGM, Voorhorst MM, Van Laar JH, Mulder E \& Trapman J 1989 The human androgen receptor: domain structure, genomic organization and regulation of expression. Journal of Steroid Biochemistry and Molecular Biology 34 307-310.

Callahan HL \& Beverley SM 1992 A member of the aldo-keto reductase family confers methotrexate resistance in Leishmania. Journal of Biological Chemistry 267 24165-24168.

Carlson JA, Roger BB, Sifers RA, Hawkins HK, Finegold MJ \& Woo SL 1988 Multiple tissues express alpha 1-antitrypsin in transgenic mice and man. Journal of Clinical Investigation 82 26-36.

Chen C \& Okayama H 1987 High-efficiency transformation of mammalian cells by plasmid DNA. Molecular and Cellular Biology 7 2745-2752.

Daoudal S, Berger M, Pailhoux E, Tournaire C, Veyssière G \& Jean Cl 1995 Cloning and expression of mouse aldose reductase. Comparison with the androgen-dependent protein from mouse vas deferens. Steroid Biochemistry (Life Science Advances) 14 45-58. 
Daoudal S, Tournaire C, Halère A, Veyssière G \& Jean Cl 1997 Isolation of the mouse aldose reductase promoter and identification of a tonicity-responsive element. Journal of Biological Chemistry 272 2615-2619.

Dassouli A, Manin M, Veyssière G \& Jean Cl 1994 Androgens regulate expression of the gene coding for a mouse vas deferens protein related to the aldo-keto reductase superfamily in epithelial cell subcultures. Journal of Steroid Biochemistry and Molecular Biology 48 121-128

Donohue PJ, Alberts GF, Hampton BS \& Winkles JA 1994 A delayed-early gene activated by fibroblast growth factor- 1 encodes a protein related to aldose reductase. Journal of Biological Chemistry 269 8604-8609.

Fabre S, Manin M, Pailhoux E, Veyssière G \& Jean Cl 1994 Identification of a functional androgen response element in the promoter of the gene for the androgen-regulated aldose reductaselike protein specific to the mouse vas deferens. Journal of Biological Chemistry $2695857-5864$.

Ferraris JD, Williams CK, Martin BM, Burg MB \& Garcia-Perez A 1994 Cloning, genomic organization and osmotic response of the aldose reductase gene. Proceedings of the National Academy of Sciences of the USA 91 10742-10746.

Grange T, de Sa CM, Oddos J \& Pictet R 1987 Human mRNA polyadenylate binding protein: evolutionary conservation of a nucleic acid binding motif. Nucleic Acids Research 25 4771-4787.

Gui T, Tanimoto T, Kokai Y \& Nishimura C 1995 Presence of a closely related subgroup in the aldo-keto reductase family of the mouse. European Journal of Biochemistry 227 448-453.

Hanukoglu I, Feuchtwanger R \& Hanukoglu A 1990 Mechanism of corticotropin and cAMP induction of mitochondrial cytochrome P450 system enzymes in adrenal cortex cells. Journal of Biological Chemistry 265 20602-20608

Hyndman DJ, Takenoshita R, Vera NL, Pang SC \& Flynn TG 1997 Cloning, sequencing, and enzymatic activity of an inducible aldo-keto reductase from chinese hamster ovary cells. Journal of Biological Chemistry 272 13286-13291.

Inoue S, Sharma RC, Schimke RT \& Simoni RD 1993 Cellular detoxification of tripeptidyl aldehydes by an aldo-keto reductase. Journal of Biological Chemistry 268 5894-5898.

Iwata N, Hara S, Nishimura C, Takahashi M, Mukai T, Takayama M \& Endo T 1996 Hormonal regulation of aldose reductase in rat ovary during the estrous cycle. European Journal of Biochemistry 235 444-448.

Jacquin-Becker C \& Labourdette G 1997 Regulation of aldose reductase expression in rat astrocytes in culture. Glia 20 135-144.

Jefcoate CR, Di Bartolomeis MJ, Williams CA \& McNamara BC 1987 ACTH regulation of cholesterol movement in isolated adrenal cells. Journal of Steroid Biochemistry and Molecular Biology 27 721-729.

John ME, John MC, Boggaram V, Simpson ER \& Waterman MR 1986 Transcriptional regulation of steroid hydroxylase genes by ACTH. Proceedings of the National Academy of Sciences of the USA 83 4715-4719.

Kinoshita JH \& Nishimura C 1988 The involvement of aldose reductase in diabetic complications. Diabetes/Metabolism Reviews 4 323-337.

Ko CB, Ruepp B, Bohren KM, Gabbay KH \& Chung SSM 1997 Identification and characterization of multiple osmotic response sequences in the human aldose reductase gene. Journal of Biological Chemistry 272 16431-16437.

Lau ET, Cao D, Lin C, Chung SK \& Chung SS 1995 Tissue-specific expression of two aldose reductase-like genes in mice: abundant expression of mouse vas deferens protein and fibroblast growth factor-regulated protein in the adrenal gland. Biochemical Journal 312 609-615.

Liu Z \& Simpson ER 1997 Steroidogenic factor 1 (SF-1) and SP1 are required for regulation of bovine CYP11A gene expression in bovine luteal cells and adrenal Y1 cells. Molecular Endocrinology 11 $127-137$.
Manin M, Veyssière G, Cheyvialle D, Chevalier M, Lecher P \& Jean Cl 1992 In vitro androgenic induction of a major protein in epithelial cell subcultures from mouse vas deferens. Endocrinology $1312378-2386$.

Martinez A, Berger M \& Jean Cl 1989 Androgen regulation of major mRNAs for proteins of the immature and adult mouse vas deferens. Journal of Endocrinology 120 67-74.

Martinez A, Berger M \& Jean Cl 1990 Androgen regulation of the mRNA encoding a major protein of the mouse vas deferens. Molecular and Cellular Endocrinology 72 201-211.

Matsuura K, Deyashiki Y, Bunai Y, Ohya I \& Hara A 1996 Aldose reductase is a major reductase for isocaproaldehyde, a product of side-chain cleavage of cholesterol, in human and animal adrenal glands. Archives of Biochemistry and Biophysics 328 265-271.

Neumann JR, Morency CA \& Russian KO 1987 A novel rapid assay for chloramphenicol acetyltransferase gene expression. Biotehniques $\mathbf{5}$ 444-447.

Pailhoux EA, Martinez A, Veyssière GM \& Jean Cl 1990 Androgen-dependent protein from mouse vas deferens. cDNA cloning and protein homology with the aldo-keto reductase superfamily. Journal of Biological Chemistry 265 19932-19936.

Parker MG, Webb P, Needham M, White K \& Ham I 1987 Identification of androgen response elements in mouse mammary tumour virus and the rat prostate C3 gene. Journal of Cellular Biochemistry 35 285-292.

Sambrook J, Fritsch EF \& Maniatis T 1989 Molecular Cloning: $A$ Laboratory Manual, edn 2, vol 1, pp 68-71. Cold Spring Harbor: Cold Spring Harbor Laboratory Press.

Simpson ER \& Waterman ER 1988 Regulation of the synthesis of steroidogenic enzymes in adrenocortical cells by ACTH. Annual Review of Physiology 50 427-440.

Spycher SE, Tabataba-Vakill S, O’Donnell VB, Palomba L \& Azzi A 1997 Aldose reductase induction: a novel response to oxidative stress of smooth muscle cells. FASEB Journal 11 181-188.

Stolz A, Rahimi-Kiani M, Ameis D, Chan E, Ronk M \& Shively JE 1991 Molecular structure of rat hepatic 3a-hydroxysteroid dehydrogenase a member of the oxido-reductase gene family. Journal of Biological Chemistry 266 15253-15257.

Stolz A, Hammond L, Lou H, Takikawa H, Ronk M \& Shively JE 1993 cDNA cloning and expression of the human hepatic like acid-binding protein a member of the monomeric reductase gene family. Journal of Biological Chemistry 268 10448-10457.

Taragnat C, Berger M \& Jean Cl 1988 Preliminary characterization, androgen-dependence and ontogeny of an abundant protein from mouse vas deferens. Journal of Reproduction and Fertility 83 835-842.

Taragnat C, Berger M \& Jean Cl 1990 Tissue and species specificity of mouse ductus deferens protein. Journal of Andrology 11 279-286.

Varma SD \& Kinoshita JH 1974 The absence of cataracts in mice with congenital hyperglycemia. Experimental Eye Research 19 $577-582$.

Warren JC, Murdock GL, Ma Y, Goodman SR \& Zimmer E 1993 Molecular cloning of testicular 20 $\alpha$-hydroxysteroid dehydrogenase: identity with aldose reductase. Biochemistry 32 1401-1406.

Yasumura Y, Buonassisi V \& Sato G 1966 Clonal analysis of differentiated function in animal cell cultures. I. Possible correlated maintenance of differentiated function and the diploid karyotype. Cancer Research 26 529-535.

Zeindl-Eberhart E, Jungblut PR, Otto A \& Rabes HM 1994 Identification of tumor-associated protein variants during rat hepato-carcinogenesis. Journal of Biological Chemistry 269 14589-14594.

Received 24 June 1998

Accepted 11 September 1998 